\title{
Public Participation for Integrated Groundwater Management: The Case of Maneadero Valley, Baja California, Mexico
}

\author{
Mariana Villada-Canela ${ }^{1, *(\mathbb{D})}$, Dalia Marcela Muñoz-Pizza ${ }^{2}$ (D) , Vanesa García-Searcy ${ }^{1,3}{ }^{(\mathbb{D}}$, \\ Raquel Camacho-López ${ }^{3}$ (D), Luis Walter Daesslé ${ }^{1}$ (D) and Leopoldo Mendoza-Espinosa ${ }^{1}$ (D) \\ 1 Instituto de Investigaciones Oceanológicas, Universidad Autónoma de Baja California, Carr. \\ Transpeninsular 3917, Ensenada 22860, BC, Mexico; garcia.vanesa@uabc.edu.mx (V.G.-S.); \\ walter@uabc.edu.mx (L.W.D.); lmendoza@uabc.edu.mx (L.M.-E.) \\ 2 Facultad de Ciencias Marinas, Universidad Autónoma de Baja California, Carr. Transpeninsular 3917, \\ Ensenada 22860, BC, Mexico; marcela.munoz@uabc.edu.mx \\ 3 Maestría en Manejo de Ecosistemas de Zonas Áridas, Facultad de Ciencias, \\ Universidad Autónoma de Baja California, Carr. Transpeninsular 3917, Ensenada 22860, BC, Mexico; \\ raquel.camacho.lopez@uabc.edu.mx \\ * Correspondence: mvilladac@uabc.edu.mx; Tel.: +52-646-152-8217
}

check for updates

Citation: Villada-Canela, M.; Muñoz-Pizza, D.M.; García-Searcy, V.; Camacho-López, R.; Daesslé, L.W.;

Mendoza-Espinosa, L. Public

Participation for Integrated Groundwater Management: The Case of Maneadero Valley, Baja California, Mexico. Water 2021, 13, 2326.

https://doi.org/10.3390/w13172326

Academic Editor: Carmen Teodosiu

Received: 16 July 2021

Accepted: 21 August 2021

Published: 25 August 2021

Publisher's Note: MDPI stays neutral with regard to jurisdictional claims in published maps and institutional affiliations.

Copyright: (c) 2021 by the authors. Licensee MDPI, Basel, Switzerland. This article is an open access article distributed under the terms and conditions of the Creative Commons Attribution (CC BY) license (https:/ / creativecommons.org/licenses/by/ $4.0 /)$.

\begin{abstract}
There is a controversy in groundwater management: some people argue that public participation has decreased efficiency in decision-making, while others believe this process is not executed effectively. Questions about whether public participation results from the context involving influential people, the rules, or the way participation mechanisms were designed need examination. In this study, opportunities, barriers, and challenges of public participation were analyzed in the management of a coastal aquifer affected by marine intrusion in the Maneadero Valley, México. Mixed methods were implemented, involving 28 interviews with key actors and 50 surveys conducted during 2014 and 2017 with groundwater users. Results show that public participation is mainly determined by power differences, lack of continuity in the participatory processes, and the design of the participation mechanisms. State actors have greater decision-making power in integrated groundwater management. In contrast, groundwater users have limited participation in the process of making proposals, and their participation is generally passive. There are limitations to broad, informed, and responsible public participation: examples of these limitations include different levels of information, inappropriate institutional arrangements, failure to disseminate scientific information, lack of spaces to exercise public participation, and absence of political will. Hence, to improve Maneadero aquifer management, it is necessary to decentralize decision-making, integrate technical and non-technical knowledge, generate scientific evidence about water availability, and give a prominent role to stakeholders and users from the initial stages. In addition, internalization and water culture are required. These results can help to guide integrated groundwater management in other arid regions.
\end{abstract}

Keywords: coastal aquifers; stakeholder engagement; community participation; groundwater governance; water policy

\section{Introduction}

Water scarcity in arid and semi-arid regions is a critical challenge in reaching wellbeing and sustainable development. These regions share physical factors such as low precipitation, high temperatures, and temporal imbalances between supply and demand, in addition to constraints in management which involve water users and stakeholders [1,2]. These factors drive the deterioration of water sources, land degradation, and biodiversity loss.

Constraints in water management have revealed the need for a more comprehensive management model, based on participatory approaches, involving stakeholders and policy makers from different levels and sectors [3]. With these considerations, integrated water 
resources management (IWRM) [4] emerges as a way to promote equity, sustainability, and responsible management of water resources.

IWRM and a sustainable development agenda, with the SDG No. 6 [5], integrate the democratization of decision-making through broader public participation. Public participation can be understood as a means through which authorities of different levels (federal representatives, regional, and state managers), users with water allocations, local or municipal managers, academia, and organized citizens try to influence water planning, policies, and projects. According to IWRM, technical projects, economic tools, regulatory frameworks, and water policies do not work without sound scientific evidence (biophysical and social) and the active, inclusive, and informed participation of those affected and interested in aquifer management [6].

However, there are some obstacles to strengthening public participation in IWRM related to the management model, centralism, institutional arrangements, funding and participatory mechanisms limited to public consultation, poor data quality, and reduced understanding of scientific facts from water users [7-14]. In addition to these challenges, there are inequalities in the characteristics and contexts of the participants, different levels of information, lack of technical and financial support, and demographic and socioeconomic factors (age, sex, education level, socioeconomic status) [13,14].

Strengthening public participation in water management is crucial in arid and semiarid regions. In Mexico, approximately $65 \%$ of the territory is dryland [15], whose groundwater sources (653 aquifers that contribute $39 \%$ of the total water volume for human uses) are overexploited (105), affected by saline soils and brackish water (32), and by marine intrusion (17) [16-18]. In Mexico, IWRM is carried out by participatory mechanisms such as councils, commissions, and committees in each watershed/basin or aquifer, irrigation districts, and water user associations, according to the National Water Act [19]. However, at the federal level, the National Water Commission (CONAGUA, by its Spanish acronym) is the national water authority, maintaining its role as the administrator of water rights allocation, duty collection, and enforcement [19].

Concerning the opportunities for public participation in water management in Mexico, there are three main arguments [20]: (1) legal, when the legal framework and current regulatory agreements are met, public participation is considered in international agreements, in national legislation, or local public policy and, therefore, it is institutionalized [7-13]; (2) ideological, referring to ways of organizing society with some degree of power, and appeals to democratic participation and governance [10,13,14]; and (3) instrumental, when different social actors provide helpful information and their participation becomes a way of promoting education and learning, thus improving decision-making [7,8,12-14].

The main participation mechanism at a local level is the Technical Groundwater Committee (COTAS, by its Spanish acronym). These participation mechanisms have been taking place over the last three decades, in which IWRM has been applied and limitations have been revealed, with consequences for water management efficiency [20]. The present study seeks to understand how groundwater is governed, in order to overcome the limitations in the decision-making processes, considering public participation. For instance, it will try to establish if public participation results from the context, the involvement of influential people, the rules shaping the process, or the way institutions were designed. The study includes actors with different interests and roles in decision-making and water users. It discusses the elements that facilitate or inhibit public participation, the challenges of its implementation, the differences related to socio-demographic characteristics, and the management perspectives and alternatives.

The present research is structured into the following sections: (1) study area description and study case which consists in analyzing interviews and surveys to identify the perspectives and perceptions of key stakeholders and water users in water management; (2) the results of each analysis considering the context of groundwater management, the openness and power-sharing, the provided space or forum, and the affected, interested, and 
key stakeholders in the study case; and (3) identification and discussion of opportunities, barriers, and challenges for public participation in the study case.

\section{Materials and Methods}

A mixed-method approach was used to inquire about public participation in groundwater management in Mexico and Ensenada, Baja California. First, 50 surveys of water users (farmers with a water allocation) were carried out in two periods: February 2014 and October 2017. Afterward, 28 semi-structured interviews were carried out with key actors (including the government, water users, academy sector, companies, COTAS, and NGOs) to assess their perceptions and opinions. The interviews were conducted between 2014 and 2020. The objectives and descriptions of each method are described in Table 1.

Table 1. Mixed method used to inquire about public participation in groundwater management.

\begin{tabular}{ccc}
\hline Method & Objective & Criteria/Main Question \\
\hline Surveys of water users, $n=50$ & $\begin{array}{c}\text { Integrate the perception of public } \\
\text { participation focused on water users, } \\
\text { considering socioeconomic characteristics } \\
\text { and type of participation }\end{array}$ & $\begin{array}{c}\text { Socioeconomic characteristics, perceived } \\
\text { problems, and solutions in groundwater } \\
\text { management. Attitudes towards public } \\
\text { participation. }\end{array}$ \\
Interview of key actors, $n=28$ & $\begin{array}{c}\text { Broaden the understanding of the } \\
\text { stakeholder's perspectives on water } \\
\text { management and public participation }\end{array}$ & $\begin{array}{c}\text { Perceptions about the main problems in } \\
\text { water management, key actors, barriers } \\
\text { to public participation and performance } \\
\text { of public participation spaces. }\end{array}$ \\
\hline
\end{tabular}

\subsection{Study Area}

In Baja California, there are 48 aquifers, 15 of which are overexploited, and 7 are coastal aquifers with seawater intrusion [16,17]. Moreover, Baja California is considered highly vulnerable to droughts [18]. The objectives of water policy in the Baja California Peninsula HAR are: (1) to guarantee human rights to water and sanitation; (2) to make efficient use of water to contribute to the sustainable development of productive sectors; (3) to reduce the vulnerability of the population to floods and droughts; (4) to preserve the integrity of the water cycle to guarantee the hydrological services provided by basins and aquifers; and (5) improve conditions for water governance to strengthen decision-making and fight corruption, based on scientific and local knowledge, but mainly, to give a relevant role to the public participation mechanisms [18,21].

The city of Ensenada, in Baja California, is selected as an example, as it faces severe problems of water scarcity and deteriorating water quality as a result of the unsustainable management of its water resources. The city depends on the coastal aquifer of Maneadero for nearly a quarter of its water supply $\left(23 \%, 226 \mathrm{~L} \mathrm{~s}^{-1}\right)$, whose administration depends on the CONAGUA and is supported by the COTAS of the Maneadero aquifer.

The Maneadero aquifer (Figure 1) belongs to the administrative hydrologic region No. 1 in northwestern Baja California. The aquifer is located $15 \mathrm{~km}$ south of the city of Ensenada $\left(31^{\circ} 38^{\prime} 65^{\prime \prime} \mathrm{N}, 31^{\circ} 30^{\prime} 26^{\prime \prime} \mathrm{W}\right)$. It is a hydrologic sub-basin covering $1975 \mathrm{~km}^{2}$, of which $75 \mathrm{~km}^{2}$ belong to a coastal plain. Maneadero Valley is bordered to the north by a fluvial terrace that separates it from Ensenada, to the south by the Agua Blanca fault, and to the west by Punta Banda Estuary that connects to Pacific Ocean [22,23].

Ninety percent of the land in Maneadero Valley is oriented to agricultural activities; its water demand is supplied by the aquifer and recently has incorporated treated wastewater [24]. The Maneadero aquifer presents a condition of intensive extraction and salinization caused by marine intrusion, with total dissolved solids (TDS) concentrations between 1.1 and $26.9 \mathrm{~g} \mathrm{~L}^{-1}$ [22-25], by far exceeding the maximum permissible limit of $1 \mathrm{~g} \mathrm{~L}^{-1}$ (Official Mexican Standard NOM-127-SSA1-1994). Nearly 300 wells are active, and the allocated volume of water is $39.06 \mathrm{hm}^{3}$, with an annual recharge of $33.7 \mathrm{hm}^{3}$, resulting in an annual deficit of $5.37 \mathrm{hm}^{3}$ [17]. In addition to overexploitation, this situation is attributed to a 
low precipitation rate that averages $252 \mathrm{~mm} \mathrm{y}^{-1}$. As a way to reduce the salinization of the Maneadero aquifer, reclaimed water (RW) for agricultural irrigation and incidental discharges on riverbeds has been used in Maneadero Valley since the summer of 2014, resulting in the sporadic detection of fecal coliforms in soil after irrigation [26] as well as a mixture of dissolved salts attributed to natural geochemical processes, anthropogenicderived processes (urban solid waste, reclaimed water, and animal waste), and marine intrusion, also affecting the aquifer recharge $[23,25]$.

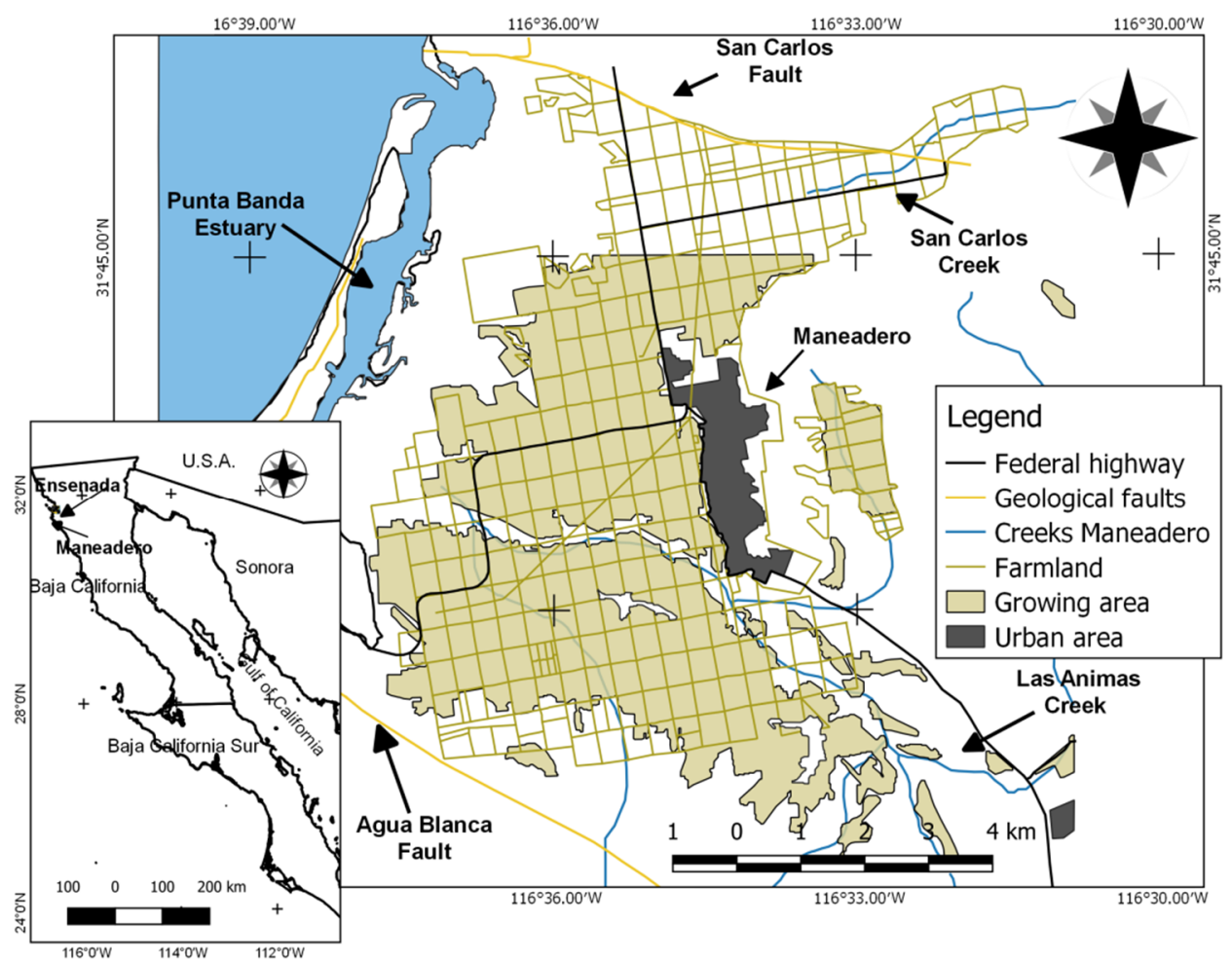

Figure 1. Localization of Maneadero Valley in Ensenada, Baja California.

Groundwater withdrawal from the Maneadero aquifer has been restricted since 1965 (limiting the drilling of new wells) [27], thus leading to reduced agricultural production and land-use change from agricultural to urban (i.e., household demands for running water and sanitation services). Furthermore, water policy is applied inefficiently: sanctions exist due to over-exploitation, but there are new allocations despite the regulations and increasing use of desalination plants for agricultural irrigation. The area has also seen increased pumping volumes because of the low price of electricity [28]. Moreover, other inefficiencies include the lack of an updated wells inventory, the lack of an updated integrated water management plan [29]; low water culture in an arid region [30], and disinformation between users and authorities regarding the groundwater quantity and quality [30]. This political situation and the natural and economic context stimulate the research and evaluation of water management options [26,28-30] that broaden knowledge about actors, institutions, regulations, and policies governing the participatory process of groundwater management in the Maneadero Valley.

\subsection{Interviews with Key Actors}

Participants from COTAS, state actors linked to water management, scientists developing knowledge to support management programs, and NGO representatives involved in program design and forums organized by COTAS and governmental institutions were identified (Table 2). The snowball technique was used to include influential actors in the interviews. 
Table 2. List of stakeholders (type of actor, institution, role/expertise).

\begin{tabular}{|c|c|c|c|}
\hline Stakeholder ${ }^{1}$ Group & Institution/Expertise & Number of Interviewees & Code \\
\hline $\begin{array}{c}\text { CONAGUA } \\
\text { (Federal and HAR level) } \\
\text { CEA, SEPROA }\end{array}$ & $\begin{array}{l}\text { Public policy, legal framework, water } \\
\text { management }\end{array}$ & 2 & $\mathrm{~F} 1, \mathrm{~F} 2$ \\
\hline $\begin{array}{l}\text { Water, agricultural } \\
\text { management } \\
\text { (State level) }\end{array}$ & $\begin{array}{l}\text { Operation and maintenance of water } \\
\text { infrastructure; agricultural research }\end{array}$ & 3 & $\mathrm{~S} 1, \mathrm{~S} 2, \mathrm{~S} 3$ \\
\hline $\begin{array}{l}\text { Human rights } \\
\text { (State level) }\end{array}$ & Water law, public participation & 1 & S4 \\
\hline $\begin{array}{c}\text { CESPE } \\
\text { Water Utility } \\
\text { (municipal level) }\end{array}$ & $\begin{array}{l}\text { Institutional development, wastewater } \\
\text { treatment plants }\end{array}$ & 3 & M1, M2, M3 \\
\hline $\begin{array}{l}\text { Urban and rural development } \\
\text { (municipal level) }\end{array}$ & Planning, public participation & 3 & M4, M5, M6 \\
\hline $\begin{array}{c}\text { Private } \\
\text { organizations }\end{array}$ & $\begin{array}{l}\text { Engineering services, agrarian } \\
\text { cooperative }\end{array}$ & 2 & P1, P2 \\
\hline $\begin{array}{l}\text { Environmental and social } \\
\text { science researchers }\end{array}$ & $\begin{array}{l}\text { Scientific evidence, environmental } \\
\text { policies }\end{array}$ & 6 & R1, R2, R3, R4, R5, R6 \\
\hline $\begin{array}{l}\text { Water users } \\
\text { (sub-basin level) }\end{array}$ & COTAS management, farming & 4 & $\mathrm{~W} 1, \mathrm{~W} 2, \mathrm{~W} 3, \mathrm{~W} 4$ \\
\hline $\begin{array}{l}\text { Non-governmental } \\
\text { organizations }\end{array}$ & $\begin{array}{l}\text { Wetland conservation, environmental } \\
\text { education, socioeconomic development }\end{array}$ & 4 & $\mathrm{O} 1, \mathrm{O} 2, \mathrm{O} 3, \mathrm{O} 4$ \\
\hline
\end{tabular}

${ }^{1}$ The groups of actors interviewed have participated in the design of programs and/or regulations to improve water management in Baja California.

The semi-structured interviews consisted of the following research questions: (1) What are the main water management problems in Ensenada and the Maneadero Valley? (2) What actors and institutions have been involved in the problem and its solutions? (3) What are the critical factors for effective public participation? (4) What are the public participation spaces? (5) Who should participate in decisions and agreements on water management? (6) What factors motivate public participation and which ones do not? (7) What is the perception of scientific evidence in decision-making? and (8) What characteristics should the actors have to guide participatory processes?

In general, each interview took between 30 and $45 \mathrm{~min}$. Interviews were tape-recorded with prior consent and later transcribed. The data were analyzed using grounded theory [31]. The codes and categories integrated factors related to the social, economic, and political context in which groundwater management decisions are made; also in addition to the obstacles and challenges associated with public participation. In this process, relevant fragments of the interviews were selected and included in the results section. The method of codification and category assignment was carried out on the Atlas.ti software (Scientific Software Development GmbH, Berlin, Germany).

The coding results were validated following the procedure described in Farmer et al. [32]. A set of seven interviews was coded. Later, the relevance of the codes, agreements, and differences was evaluated. The remaining interviews were coded based on the established codes in the previous stages. Categories were created to group the related codes.

\subsection{Surveys to Farmers Using Groundwater}

The surveys were conducted in two periods: the first in February 2014 (before agricultural irrigation with reclaimed water in the Maneadero Valley) and the second three years later, in October 2017. The purpose of the second survey was to evaluate changes in the perception of water users regarding the implementation of strategies to reduce the problem of aquifer overexploitation and factors related to public participation. The sample size included approximately $35 \%$ of the total registered water users (206 registered users) with 
a confidence level of 90\% using Slovin's formula [33], the sample size was 67. However, only 50 were fully completed, and the questionnaires were applied face to face.

The first section of the questionnaire included questions on socioeconomic variables (sex, age, education level, and monthly household income).The second section integrated questions about the perception of problems associated with water use (overexploitation, marine intrusion, scarcity, and lack of water coverage); in the third section, the questions were formulated to address the attitudes towards water management (implementation of agricultural irrigation with treated wastewater (reclaimed water), treated wastewater discharged into riverbeds to maintain freshwater supplies, desalination plants). A Likert scale from "totally agree" to "totally disagree" was used in the last questions. The last section focused on the attitudes towards public participation, considering perception about meetings, type of participation, and use of information.

The interview findings were contrasted with the perception of water users towards the opportunities for participation and usefulness of their public interventions in groundwater management.

\section{Results and Discussion}

\subsection{Interviews with Actors}

Thirty-three codes emerged from the codification process. These were matched to the five categories identified in the interview analysis. The categories and codes are described in Table 3. Codes grouped in these categories represent relevant elements of public participation in water management in Ensenada and the Maneadero Valley.

Table 3. List of categories and codes.

\begin{tabular}{|c|c|}
\hline Category & Code \\
\hline \multirow[t]{4}{*}{ 1. Water management in the Maneadero Valley } & 1.1 Main problems of water management in Maneadero \\
\hline & 1.2 Responsibility for water management \\
\hline & 1.3 Objective of water management \\
\hline & 1.4 Different views on the Maneadero aquifer or the reclaimed water \\
\hline \multirow[t]{5}{*}{ 2. The role of stakeholders and sectors in water management } & 2.1 Main actors in water management \\
\hline & 2.2 Most influential actors \\
\hline & 2.3 Less influential actors \\
\hline & 2.4 Experience in creating plans related to water \\
\hline & 2.5 How stakeholders are viewed in management \\
\hline \multirow[t]{10}{*}{ 3. Obstacles to public participation in water management } & 3.1 Current water administration \\
\hline & 3.2 Need for more studies on water availability \\
\hline & 3.3 Lack of interest in participation for water management \\
\hline & 3.4 Lack of support for contributions from scientists \\
\hline & 3.5 Lack of political will \\
\hline & 3.6 Social apathy \\
\hline & 3.7 Limited participation/decision spaces \\
\hline & 3.8 Purpose of participation spaces \\
\hline & 3.9 Lack of evidence of the water quantity and quality \\
\hline & 3.10 Ineffective application of legislation \\
\hline \multirow{7}{*}{$\begin{array}{l}\text { 4. Opportunities for public participation in water } \\
\text { management }\end{array}$} & 4.1 Current role of COTAS \\
\hline & 4.2 COTAS operation \\
\hline & 4.3 Actors who have facilitated water management \\
\hline & 4.4 Leadership and Support \\
\hline & 4.5 Facilitator characteristics \\
\hline & 4.6 Moments of inclusion in water management \\
\hline & 4.7 The role of scientific information in decision-making \\
\hline \multirow{8}{*}{ 5. Solutions to water management problems } & 5.1 Relevant projects \\
\hline & 5.2 Project proposals \\
\hline & 5.3 Responsibility for financing solutions \\
\hline & 5.4 Water as a government priority \\
\hline & 5.5 Freewill of all stakeholders \\
\hline & 5.6 Encourage active participation \\
\hline & 5.7 Desalination plants, reclaimed wastewater, regulations of water use \\
\hline & 5.8 Science outreach \\
\hline
\end{tabular}




\subsubsection{Water Management in the Maneadero Valley: Perceptions}

According to the interviewees, lack of knowledge and data about the availability, quantity, and quality of the water resource are historical problems in Ensenada. While the interviewees recognize some progress-e.g., the operation of the aqueduct called "Flujo Inverso," (inverse flux of water supplied from the Colorado River through Tijuana)-they pointed out the lack of solutions to prevent the aquifer's deterioration (like seawater intrusion) and the lack of regulations on the use of groundwater.

Interviewed actors from the academic, governmental, and NGO sectors think agriculture is the leading water consumer and that there is limited public knowledge of Ensenada as a semi-arid zone. Regarding water policy decisions, from the stakeholders' perspective, the use of water for agricultural irrigation is the most important. Small desalinization plants for agriculture irrigation have also been mentioned as a solution to obtain better water quality. These perceptions are in agreement with previous findings [34], which pointed out wastewater irrigation at a regional and national level as a relevant resource for IWRM.

The private organizations (engineering services, agrarian cooperative) and farmers points of view about technical solutions for water management (aquifer recharge, reclaimed water reuse, desalinization plants) are different. Even when farming systems have become more efficient (drip irrigation, greenhouses, hydroponics), the idea of saving water persists with the main purpose of increasing the cultivation area, obtaining a higher production despite the aquifer degradation:

"We [producers and farmers] are the main social actors. We have great interest in continuing to produce. We want to increase the cultivated area, but how can we increase it if we cannot obtain water with good quality? Or if the water we need is becoming more and more expensive?" (P1)

The concern about water quality for irrigation has been considered in regions where water reuse is common, however, the evidence concerning irrigation guidelines has shown the relevance of constant monitoring, and the inclusion of specific variables as quality indicators of agricultural soil [35]. In addition to technical aspects, the relevance of a close communication between local authorities and farmers to monitor and suggest solutions, and the challenge of institutional arrangements were pointed out [26]. Interviewed stakeholders agree with these findings, and mentioned obstacles related to the legal framework and social and political factors. The interviewees from the governmental sector showed that, according to the law, the most important water use is public-urban. However, agriculture is the main water user in Ensenada. Such distribution has raised social conflicts. On the other hand, farmers' sectors recognized legal aspects influencing surveillance and concessions:

"The Maneadero aquifer is supposed to be closed. There is no way to obtain an allocation, unless someone else donates a volume of water or transfers the allocation rights. But, measurements of water extracted are not always carried out or exceed the established amounts, which has resulted in penalties for farmers (groundwater users)."(W2)

As a response to these issues, institutional arrangements and public participation in the government's projects and implementations have shown positive correlation with agriculture efficiency and restauration of the aquifer's conditions [36].

\subsubsection{Water Management in the Maneadero Valley: The Role of Stakeholders and Sectors}

The role of stakeholders is perceived in two ways; through legal faculties and the characteristics and functions that in practice each sector performs in decision making. Responsibility for supplying, conducting, distributing, and purifying water, and treating wastewater in Ensenada rests with CESPE (Ensenada State Public Services Commission, by its acronym in Spanish), the water utility at the municipality level [37]. The water infrastructure at the state level is managed by CEA-SEPROA (State Water Commission, Ministry for Water Management, Sanitation and Protection) [38]. COTAS has functions 
at the basin level, in a consultative manner, and has limited faculties at a financial or operational level [39].

Other roles have been given to some private-sector actors, such as the Business Coordinating Advisory Board (CONSULTEN, by its acronym in Spanish) and the Economic Development Council for Ensenada (CODEEN, by its acronym in Spanish) whose participation in the municipal strategic plan vision 2034 [40] is linked to particular governmental initiatives and does not have a managerial or operational role.

At the municipal level, the Metropolitan Institute for Research and Planning (IMIP) [41] is the institution that has arranged public participation spaces for different types of actors and provides technical information. IMIP has coordinated two water management programs (PIAE and PIAME, at Ensenada's city and municipal level, respectively) as a long-term guide to CESPE.

The scientific sector comprises academic, research, and technical institutions that address biophysics, engineering, and social aspects. Interviewees consider they have played a role as information providers to influence water management decisions in Maneadero, Guadalupe, and Ensenada, and have acted as an essential link to keep the stakeholders informed.

In addition to legal faculties, the interviewee's role was determined for characteristics such as scientific and technical knowledge, experience, interest, and economic power. About these characteristics, political will and leadership were recognized as critical in taking a proactive role and facilitating the participation and activity of the water users. For instance, facilitative leadership can promote a clearer process, empower weaker stakeholders, break imbalances among stakeholders and users, gather and encourage participation of important sectors in water management, and operate over institutional barriers [42,43].

Although the interviewed actors in the government sector are aware of their institutional capacities, they perceive a reduced margin of action in water management because the plans and programs do not regularly benefit from long-term planning, nor do they have enough financial resources to execute them.

In particular, COTAS is an important institution that has allowed farmers to organize and exercise their participation and create bonds with the community and government. In addition, there are other private actors such as companies and international organizations, whose role is to provide financing. Concerning the role of COTAS in water management, the interviewees considered these entities to have great power in the decision making.

Overall, there is consensus that each actor has facilitated water management. The most mentioned were COTAS and water users recognized by the community for their commitment to the development of the Maneadero Valley. From the interviewees, it can be seen that facilitating the participation process is not determined in the same way for each individual group. Each group has characteristics that contribute to make the process easier. For instance, the scientists were identified as providing neutral opinions whereas water users (tenant or owner farmers) were recognized for their experience and practical knowledge of the aquifer.

\subsubsection{Obstacles to Public Participation in Water Management}

The interviewees pointed out obstacles related to deficiencies in the institutional capacity. Among them, a critical issue is the lack of coordination between federal and local authorities. In addition, they mentioned that centralization in water management and decision-making overlooked proposals formulated by local stakeholders. For instance, some studies promote decentralization but in practice this is not enforced; although a relevant role is assigned to local authorities to promote coordination and public participation, all relevant decisions are centralized [44,45]. This fact and disagreements about the faculties of each institution associated with the legal framework are critical barriers. Co-production could be a way to enhance scientific accountability to society ("logic of accountability"), to ensure the implementation of scientific knowledge in society ("logic of 
impact"), and to include the knowledge, perspectives, and experiences of extra-scientific actors in scientific knowledge production ("logic of humility") [46].

Other obstacles that were also identified within institutions were the technical and scientific capacities of their human resources, and the lack of transparency in the selection of personnel for managerial positions. Issues such as professionalization and experience have a high value in incentivizing public participation and good governance [44,45]. Additionally, the differences in information and knowledge represent a barrier between the different actors. Studies about economic viability and technical aspects are not adequately disseminated among all stakeholders, making effective participation difficult.

Other obstacles are related to the participation mechanisms. Some respondents considered that there are no public spaces to establish dialogue. In the case of COTAS, the participation mechanisms such as assemblies are not inclusive, and some users perceive themselves as underrepresented:

"If they invite us to participate, we will get involved. We are aware of the water scarcity, and we are an important piece that must be taken into account, apart from being the only agricultural zone in Ensenada city that unfortunately tends to disappear." (W3)

Therefore, a critical barrier is a lack of motivation to participate in institutionalized mechanisms for public participation, such as COTAS, in addition to the lack of technical information about the Maneadero aquifer conditions. The result is apathy. The lack of interest influences the reduced participation of local actors. Moreover, in many cases, the efforts to create communication channels and dialogue spaces are not valued enough to take advantage of them. In this perspective, some cases refer to information access, the format, and scientific language as an obstacle because the information is not understandable enough for most water users. Consistent with these barriers, the design and objective of the participation mechanisms are essential when there is a genuine interest by actors in exercising effective public participation or legitimizing purposes. Two schemes were identified in the interviews: one featuring small groups with similar interests where participation occurs from the initial phases, and one in which more sectors participate, but the authorities are limited to presenting results and with little entailment. In the last case, some farmers' low educational level is considered a barrier for whose prioritize technical aspects:

"The dialogue spaces are not created to make a difference; they are just to justify that you were listened. But also, as citizens, we have to learn to participate better in spaces such as forums." (O1)

On the other hand, survey respondents recognized a lack of participation and a water culture that did not promote proactive participation. At the same time, crucial obstacles concerning the decision maker's characteristics emerge, such as lack of leadership and political will at the federal and local level to promote greater accountability and transparency in processes and to follow-up on proposals.

\subsubsection{Opportunities for Public Participation in Water Management}

A relevant area of opportunity to make information available and overcome barriers relies on the scientific community's role and inter-agency coordination. The commitment of the academic actors and authorities to disseminate the information contributes to the diagnosis, strategic planning, and effective participation of the water users:

"Academics must communicate their work to the community in an easier format. Their work helps us because we use it in committees. In my case, I always try to document myself about the water problems." (O2)

Water management in the Maneadero Valley has a broad scientific community interested in its environmental issues, with experience and initiative to approach the actors and participate in decision-making. This element is one of the strengths that the interviewees pointed out. However, $20 \%$ of interviewees perceive a lack of practical vision in the par- 
ticipation of the scientific group, even when CICESE and UABC academics have helped Maneadero achieve the reuse of treated wastewater.

Organizational values and culture were also identified as opportunities to promote public participation. The leadership in decision-makers of institutions at the state level has contributed to the participation of other important sectors in the integral management of water resources. Accordingly, fostering relationships of trust, teamwork, and reciprocity are desirable qualities in increasing the greater importance of public participation. In addition, the presence of an external facilitator-neutral to scientific, economic and political interests-was recognized as a relevant factor. A facilitator or intermediary has influence in mediating the interaction between the key actors, creating empathy with the different water users, adapting to emergent outcomes, and following up on the proposals [47]. This role was attributed to the academic sector for its external expertise and capacity to initiate or restore dialogue and discussion [48].

In the Maneadero Valley, the facilitator or intermediary role was also identified as part of COTAS's functions. This role requires creating links with the community, promoting consensus among users, transmitting information, and offering dialogue spaces where users can present their needs and problems. These are identified as critical factors to strengthen and contribute to public participation:

"I have visited the COTAS Maneadero, and they have helped me obtain technical information on the wells that are close to a discharge from CESPE" (M3)

\subsubsection{Plausible Solutions to Water Management Problems}

There exists consensus on reusing treated wastewater for irrigation and the desalination of groundwater as an answer to the aquifer's deterioration. The Maneadero Valley represents an example, recognized by the interviewees, of a successful effort to implement reclaimed water reuse with the collaboration and participation of all actors. However, several information gaps remain regarding infiltration processes or planting tolerant crops in areas lagging due to salinity. These reasons usually constitute points of conflict between different actors and sectors [30].

The proposed solutions mentioned by the different groups of interviewees addressed three themes: (1) broadening planning horizons in the medium and long term; (2) the mechanism of financing, infrastructure, and agreements for the conservation of the resource, and (3) synergies between actors to achieve effective public participation in the decision making. Regarding long-term strategies, local authorities and farmers' cooperatives identify academia as a possible facilitator to give continuity to these processes and strengthen the participation of water users.

Concerning financing, three sources were mentioned: government, private institutions (international organizations, companies), and water users. Water users and academics perceive government support as the primary source of financing, moving to other schemes with greater community participation. From the interviews, it was possible to identify the need for new approaches to generate outstanding community commitment and awareness of the monetary value of the resource use. Contributing to the financing of specific conservation projects at the local level, or strengthening participation through citizen observatories or citizen committees were mentioned as possible solutions by the interviewees.

In contrast, solutions financed by private companies cause greater mistrust in the actors because particular interests are often prioritized:

"I think private organizations could participate, but given that the water supply is strategic, it is not so convenient, because whoever invests always seeks profitability." (M5)

"Not everything is the government's fault. Users must also invest in protecting their resources, and part of that is financing the implementation of projects." (R1)

In agreement with these interviewees' perceptions, some communities in Latin American countries have carried out financing approaches though voluntary and decentralized 
schemes for financing watershed conservation and have obtained long-term benefits that eventually generate a culture of conservation, the efficiency of agricultural production, and provide a space for co-production, knowledge exchange and improve decision-making [49].

Water users, particularly those who participate in COTAS and authorities at the municipal level, stressed the need to implement better irrigation practices, select crops with better adaptation to saline conditions, and expand efforts to conduct studies on water quantity and quality, as well as the dissemination of technical information to the community.

The issue of water allocations is a severe problem in the Maneadero Valley. Local authorities have mentioned the need to change the current scheme with the active participation of users seeking more equitable and regulated access. Coordination between government sector and institutions (the Ministry for the Management, Sanitation, and Protection of Water, the Ministry of Sustainable Economic and Tourism, and the Ministry of Agriculture and Rural Development) is critical for these proposed solutions. Interviewees identified a need to develop synergies at rural and urban levels to propose and implement projects with a vision that can contribute towards better water management.

\subsection{Individual Contextual Factors, Opportunities and Barriers from the Groundwater Users' (Farmers) Perspective}

\subsubsection{Descriptive Statistics of the Surveys 2014 and 2017}

Table 4 shows the socio-demographic characteristics of the samples taken in 2014 and 2017. There is a serious concern among water users about the problem of aquifer overexploitation; $80 \%$ of respondents consider it to be one of the main problems in groundwater management. From the surveys conducted in $2014,75 \%$ expressed a serious concern; this percentage increased to $89 \%$ for the survey in 2017.

Table 4. Demographics and socioeconomic attributes of the respondents.

\begin{tabular}{|c|c|c|c|c|}
\hline Variable & Categories & Survey $2014(N=50)$ & Survey $2017(N=50)$ & Total \\
\hline \multirow{4}{*}{ Age } & $<52$ & $14(28 \%)$ & $11(22 \%)$ & $25(25 \%)$ \\
\hline & $\geq 52$ and $<61$ & $14(28 \%)$ & $7(14 \%)$ & $21(21 \%)$ \\
\hline & $\geq 61$ and $<68$ & $12(24 \%)$ & $16(32 \%)$ & $28(28 \%)$ \\
\hline & $\geq 68$ & $10(20 \%)$ & $16(32 \%)$ & $26(26 \%)$ \\
\hline \multirow{2}{*}{ Sex } & Female & $9(18 \%)$ & $14(28 \%)$ & $23(23 \%)$ \\
\hline & Male & $41(82 \%)$ & $36(72 \%)$ & $77(77 \%)$ \\
\hline \multirow{5}{*}{ Education level } & No schooling & $3(6 \%)$ & $2(4 \%)$ & $5(5 \%)$ \\
\hline & Elementary school & $25(50 \%)$ & $23(46 \%)$ & $48(48 \%)$ \\
\hline & High school & $8(16 \%)$ & $12(24 \%)$ & $20(20 \%)$ \\
\hline & Bachelor's degree & $11(22 \%)$ & $9(18 \%)$ & $20(20 \%)$ \\
\hline & Graduate school & $3(6 \%)$ & $4(8 \%)$ & $7(7 \%)$ \\
\hline \multirow{5}{*}{$\begin{array}{l}\text { Monthly income } \\
\text { (Mexican pesos) }\end{array}$} & $<2000$ & $10(20 \%)$ & $2(4 \%)$ & $12(12 \%)$ \\
\hline & From 2000 to 10,000 & $21(42 \%)$ & $25(50 \%)$ & $46(46 \%)$ \\
\hline & From 11,000 to 20,000 & $10(20 \%)$ & $13(26 \%)$ & $23(23 \%)$ \\
\hline & From 21,000 to 30,000 & $5(10 \%)$ & $5(10 \%)$ & $10(10 \%)$ \\
\hline & $>30,000$ & $4(8 \%)$ & $5(10 \%)$ & $9(9 \%)$ \\
\hline
\end{tabular}

In general, $77 \%$ of the respondents were male and $23 \%$ female. The mean age in the 2014 and 2017 surveys was 57 and 62 years, respectively. For 2014, the minimum age was 28 years. In the 2017 sample, the minimum age was 34 years. Educational level was elementary school 50\%, and $46 \%$ for 2014 and 2017, respectively. Lower-income level 
categories were reported in a higher percentage for the respondents in both surveys; $46 \%$ reported a monthly income between 2000 to 10,000 Mexican pesos (equivalent to 150.5 and 752.4, 2014 USD). Most respondents have agriculture as their main economic activity (75\%).

\subsubsection{Water Users' Perspectives on Water Management and Proposed Solutions}

Results from both surveys shown that water users consider that the main problems of the aquifer are due to saline intrusion (23\%), overexploitation (21\%), lack of rain in the region $(21 \%)$, the inefficient application of norms and regulations $(14 \%)$, pollution, removing rocks and sand from creeks (13\%), and infrastructure deficiencies ( $8 \%)$. Among the solutions perceived as more effective in reducing overexploitation of the aquifer (on a Likert scale from "totally agree" to "disagree"), a higher percentage of the users considered to agree with the use of treated wastewater in agriculture (24\%), recharging the aquifer with the treated wastewater $(22 \%)$, and installing desalination plants or other technologies $(17 \%)$ for crop irrigation.

The use of treated wastewater has been widely promoted to reduce overexploitation of the aquifer and increase agricultural activity in the region. Response from both surveys indicates that this measure has been beneficial for irrigating crops and the artificial recharge of the aquifer $(88 \%)$.

However, in the most recent survey (2017), users also expressed some concern about irrigating their crops with treated wastewater (31\%). Among the most common concerns are bacteriological contamination, technical problems that may affect a tertiary treatment, or the inability to use this water for vegetables or other crops for export or human consumption. Many users are not aware of the investigations carried out in Maneadero (51\%), where topics such as short-term effects on agricultural soil, and the legal framework and international guidelines have been addressed in the use of reclaimed water in the valley $[25,35])$. The dissemination of information has not been widespread. Only $41 \%$ of the respondents reported they received information on the results of the investigations carried out in the Maneadero Valley; of this percentage, the majority identified COTAS and farmers with allocations as actors which provide information and $7 \%$ of the users mentioned that academics are the information providers.

Another important fact is the perception of the institutions involved in water management in the Maneadero Valley. The water users' responses reflect no clear idea of the actors and institutions involved in water management. Forty percent of users consider that COTAS has responsibility, $30 \%$ consider a joint responsibility of the farmers with a groundwater allocation, CESPE, COTAS, and CONAGUA. In contrast, $18 \%$ consider that water management is only the responsibility of CONAGUA, $\%$ considered that CESPE is in charge, and $8 \%$ of the users admit not knowing who is in charge. This information is essential to promote consensual public participation. The sense of responsibility and knowledge of authorities in charge is a critical factor to engage participation in the management process [50], generate pro-environmental behaviors and union among community members.

\subsubsection{Perception of Dialogue Spaces, Type of Participation and Barriers to} Public Participation

This section presents the water users' perspectives regarding meeting spaces and their opinion about the effectiveness of meetings. Most respondents considered that there are spaces of dialogue; the COTAS meetings were the most important. The percentages were $88 \%$ for the 2014 survey and $80 \%$ for the 2017 survey. Figure 2 shows the perception that water users have about meetings to exercise public participation and the relevance of their opinions if they consider that their opinions are taken into account or not. The percentage of water users thinking their opinion is not taken into account increased from $14 \%$ in 2014 to $37 \%$ in 2017, for respondents perceiving enough dialogue spaces. This tendency is opposed by those surveyed who identify a lack of participation spaces, see left column in each panel of Figure 2. 


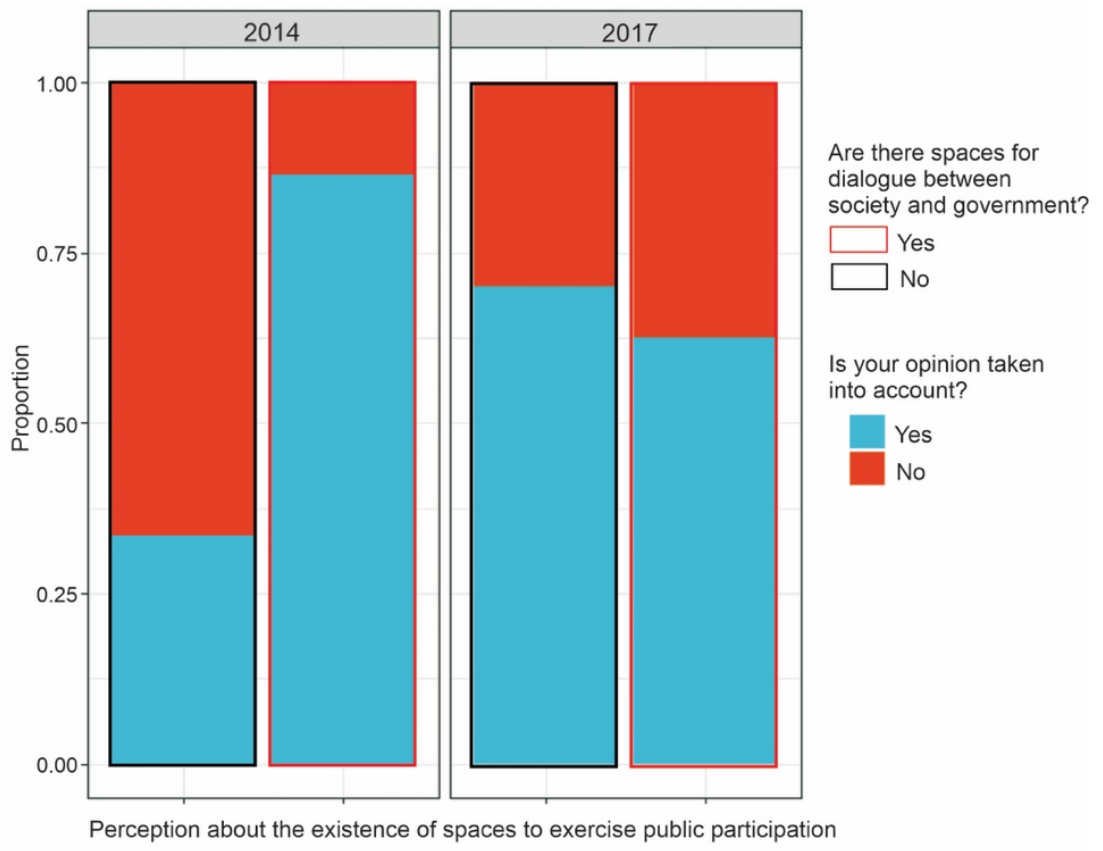

Figure 2. Perception about the existence of dialogue spaces and relevance of public opinion: Left bars are the proportions of responses from the 2014 survey. Right bars represent the proportion associated with the responses from the 2017 survey. The responses about the existence of dialogue spaces between society and government correspond to red and black rectangles for "yes" and "no", respectively, and responses for the question "Is your opinion taken into account?" correspond to blue and orange colors for "yes" and "no", respectively.

Participants perceive themselves as having an instrumental role. This absence of effective resources and dialogue spaces in the sample was associated with lack of time, staff (which delays decision-making and exposes users to constant modifications), lack of will or motivation among participants, reticence on the part of the authorities to consider opposing viewpoints, individual personalities of key players, and discouragement, disappointment, and frustration of the water users and non-governmental actors, in agreement with barriers reported in previous studies $[7,8,11,14]$.

Among the identified problems, one important issue is how water users are informed about the meeting dates. The majority of respondents answered that they are not informed (53\%), 36\% mentioned that they are informed by COTAS or local authorities, and $11 \%$ pointed to academics as having informed them about the spaces for presenting technical information on the aquifer. Regarding the role of scientific evidence in these meetings, respondents mentioned that the benefits and limitations of the research are freely discussed, but only $47 \%$ consider that the scientific information presented is sufficient or accessible. The use of language and technical jargon and information asymmetries among participants about the functioning of the environmental system (surface water versus groundwater; transboundary aquifers) was identified as an obstacle, in accordance with Villada-Canela et al. [30]. Translating the scientific information and technical terms to realities more familiar with water users is essential [51].

In general, the respondents participate in meetings with COTAS or local authorities. However, the percentage of those who reported attendance decreased from $96 \%$ in 2014 to $88 \%$ in 2017. Those who attended the meetings were asked about their type of participation. Figure 3 shows the results according to respondents' demographic and socioeconomic characteristics. 


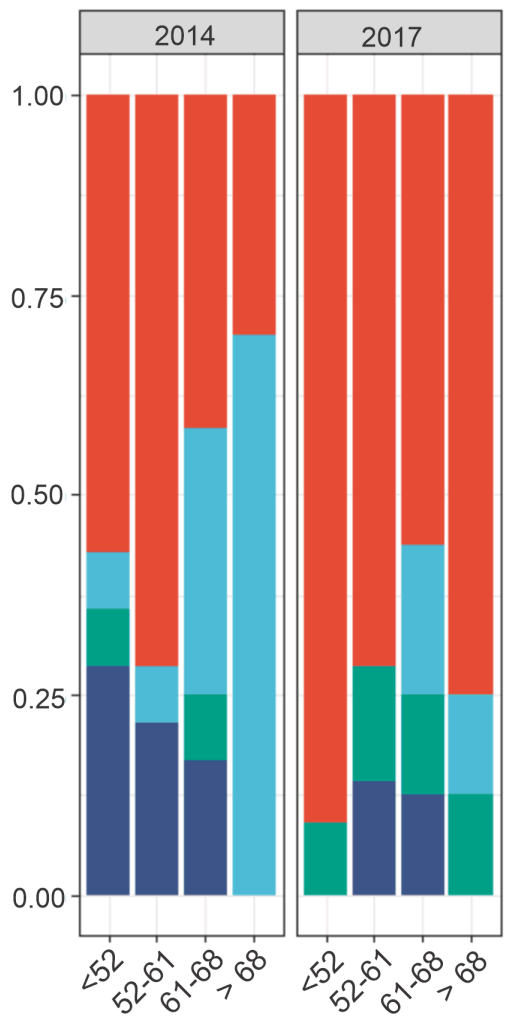

(a) Range of age

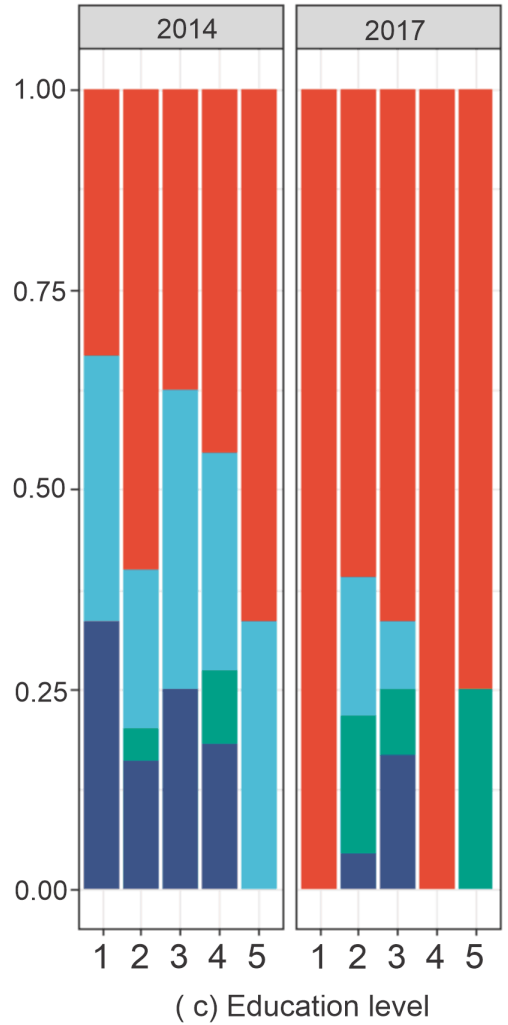

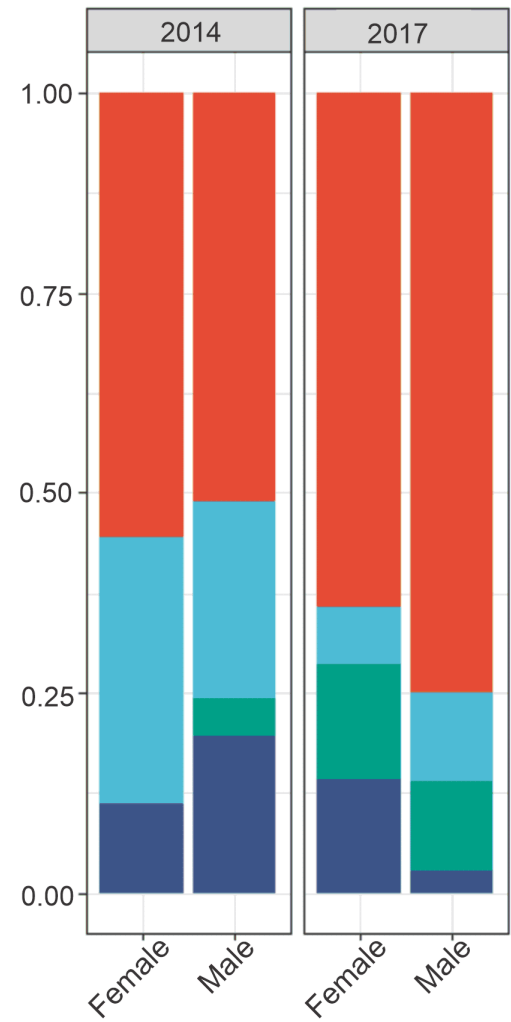

(b) Sex

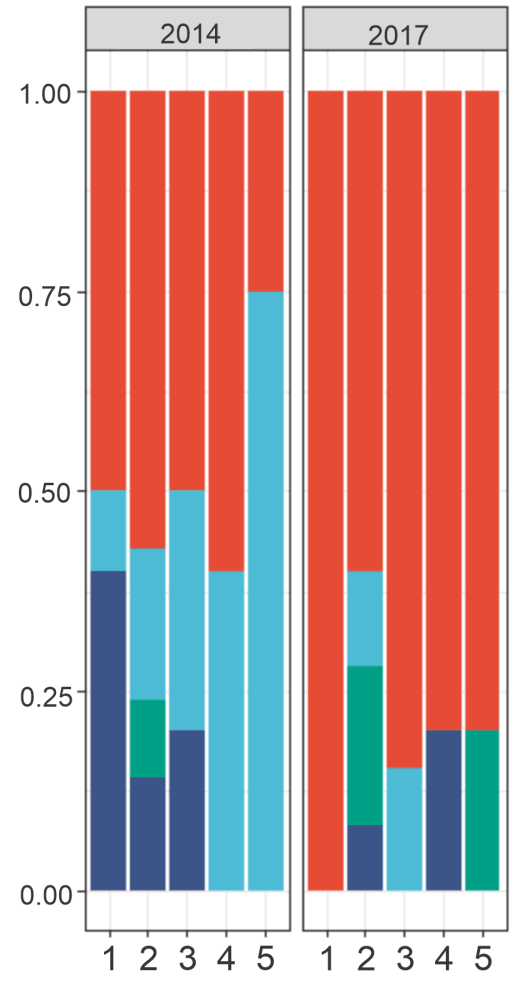

(d) Monthly income
Type of participation

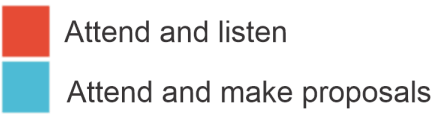

Not attending to meeting spaces

Attend and support the proposal of others

Education level

1. No schooling

2. Elementary

3. High shool

4. Bachelor's degree

5. Graduate school

\section{Monthly income}

1. $<2000$

2. 2000 to 10000

3. 11000 to 20000

4. 21000 to 30000

5. $>30000$

Figure 3. Types of participation by socioeconomic characteristics and survey application period: (a) fractions of responses by range of age; (b) fraction of responses by gender; (c) fraction of responses by level of schooling; (d) fraction of responses by categories of reported monthly income.

It is possible to observe a higher fraction of younger respondents attending the meeting. In both samples, higher proportions of active participation in the categories over 61 years 
old were found (Figure 3a). Similar proportions between males and females were observed in each group (Figure 3b); however, females (2014 sample) show a higher fraction of active participation.

A passive role in the spaces remains with a higher proportion across the education level categories (Figure 3c). For higher education levels, it is possible to note a slightly higher number of respondents actively participating in making proposals or supporting proposals from others. Formal education is an obstacle that limited public participation. Specifically, a low educational level acts as a barrier that increases when scientific evidence is not presented in formats accessible to wider audiences. Previous studies have established a direct link between education level and willingness to participate [50,52].

Figure $3 \mathrm{~d}$ shows the type of participation by monthly income categories. Here it is possible to observe that users with higher incomes made proposals in the dialogue spaces (survey 2014), while in the 2017 sample, there is a greater consensus, expressing attendance in the spaces but with no participation. Income level appears as a relevant factor in active public participation, in agreement with [53]. However, there is no consensus about the relevance of this factor, mainly because the information about the farmers' income level can be a sensitive question and is not always correctly reported [54]. While education and income levels show relevance as a driver of active participation, gender appears less decisive in the differences between the types of participation exercised in both surveys. Although the results show that males had slightly higher percentages of active participation than females, in agreement with Wanjala [55], these results suggest the need for strategies to disseminate knowledge and decision-making with a more inclusive vision.

Although interviews and surveys show that COTAS Maneadero performance represents an opportunity for public participation, the legal, institutional, and national policy frameworks do not describe how public participation is institutionalized [30]. There is no specific mention of COTAS' organizational scheme, nor its structure and faculties. Stakeholders, water users, academics, and non-governmental organizations recognized the existence of dialogue spaces; this does not imply effective participation. The survey results revealed that most users consider that dialogue spaces exist and that COTAS is their leading promoter, but user opinions must be considered. Therefore, these spaces need to be more effective, for example, with their own financing, considering users' proposals in the plans, and greater transparency and information access.

\section{Conclusions}

The present study highlights the opportunities, barriers, and challenges to establish economically feasible, socially acceptable, and environmentally sustainable aquifer management to meet an integrated groundwater management, especially on public participation issues. This research demonstrates that the water users' experiences with groundwater problems in the Maneadero Valley need to be considered to create more efficient and effective public policies and other solutions including all the stakeholders, to move towards decision-making under a democratic governance framework. In this context, COTAS emerges as the best existing space for dialogue and exchange of information between users, reinforced with the academy's support. Nevertheless, decision-making in COTAS has become a formal process not suited for the establishment of measures to reverse the deterioration of the Maneadero aquifer. Instead, CONAGUA and the group of tenant or owner farmers of Sánchez Taboada in Maneadero have greater power over decisions regarding the management of the valley's water. In this sense, new national regulations (like the Mexican General Water Law) may provide a more prominent role for COTAS as a participation mechanism and more economic resources that guarantee effective participation.

Centralized decision-making, lack of openness, and lack of institutional capacities of the state actors on water management at the local and federal levels constitute relevant barriers. Some of these limitations can be surpassed by coordinating efforts between CONAGUA, CEA-SEPROA, CESPE, and COTAS to carry out actions for the Maneadero aquifer and allocate resources for the performance of their functions. 
This study contributes to previous evidence on water management in the Maneadero Valley integrating and expanding the knowledge about public participation in groundwater management. Further research is needed to determine: (1) the real water availability in Maneadero basin, (2) aquifer regulation, (3) collective financing mechanisms for aquifer conservation (agricultural activities, urban supply, and public services), (4) challenges in achieving an effective decentralization system applied to the groundwater management, and (5) water management models with perspective on human right and ecological economy.

Author Contributions: Conceptualization, M.V.-C.; methodology, M.V.-C. and D.M.M.-P.; software, M.V.-C. and D.M.M.-P.; validation, M.V.-C., V.G.-S. and D.M.M.-P.; formal analysis, M.V.-C., V.G.S. and D.M.M.-P.; investigation, M.V.-C., V.G.-S. and R.C.-L.; writing—original draft preparation, M.V.-C. and D.M.M.-P.; writing-review and editing, M.V.-C., D.M.M.-P., V.G.-S., L.W.D., L.M.-E.; project administration, M.V.-C.; funding acquisition, M.V.-C. All authors have read and agreed to the published version of the manuscript.

Funding: This research was funded by Universidad Autónoma de Baja California, project: Public participation in integrated water management in Ensenada, Baja California: The case of Maneadero Valley. Funding call No. XVII.

Institutional Review Board Statement: All respondents of questionnaire and key experts' interviews are not mentioned by name. Results are aggregated and cannot be traced back to individual persons. Ethical review and approval were waived for this study, due to the study not being medical research (to which the Declaration of Helsinki applies).

Informed Consent Statement: All persons involved in the study participated voluntary and agreed the publication of results derived from their responses.

Data Availability Statement: The data are not publicly available due to anonymity promised to respondents and key experts. The study does not report personally identifiable data.

Acknowledgments: We thank the anonymous reviewers for their helpful comments and suggestions. We thank the financial support from Universidad Autónoma de Baja California (UABC). We acknowledge the support in fielding our survey to Eng. Alejandro Guzmán Ángel, technical manager for COTAS Maneadero. We also acknowledge scholarships from the Mexican Council for Science and Technology (CONACYT).

Conflicts of Interest: The authors declare no conflict of interest.

\section{References}

1. Koundouri, P.; Karousakis, K.; Assimacopoulos, D.; Jeffrey, P.; Lange, M.A. (Eds.) Water Management in Arid and Semi-Arid Regions: Interdisciplinary Perspectives; Edward Elgar Publishing: Northampton, UK, 2006; ISBN 978-184-542-423-7.

2. Chitsaz, N.; Azarnivand, A. Water scarcity management in arid regions based on an extended multiple criteria technique. Water Resour. Manag. 2017, 31, 233-250. [CrossRef]

3. Foster, S.; Ait-Kadi, M. Integrated water resources management (IWRM): How does groundwater fit in? Hydrogeol. J. 2012, 20, 415-418. [CrossRef]

4. Global Water Partnership [GWP]. Integrated Water Resources Management. Tack Background Papers No. 4; GWP Secretariat: Stockholm, Sweden, 2000.

5. United Nations. Transforming Our World: The 2030 Agenda for Sustainable Development; A/RES/70/L.1.Resolution adopted by the General Assembly; United Nations: New York, NY, USA, 2015.

6. Jakeman, A.J.; Barreteau, O.; Hunt, R.J.; Rinaudo, J.-D.; Ross, A. (Eds.) Integrated Groundwater Management; Springer International Publishing: Cham, Switzerland, 2016; ISBN 978-3-319-23576-9.

7. Sanchez, R.; Eckstein, G. Groundwater management in the borderlands of Mexico and Texas: The beauty of the unknown, the negligence of the present, and the way forward. Water Resour. Res. 2020, 56, 1-20. [CrossRef]

8. Hoogesteger, J.; Wester, P. Regulating groundwater use: The challenges of policy implementation in Guanajuato, Central Mexico. Environ. Sci. Policy 2017, 77, 107-113. [CrossRef]

9. Sanchez, R.; Eckstein, G. Aquifers Shared Between Mexico and the United States: Management Perspectives and Their Transboundary Nature. Groundwater 2017, 55, 495-505. [CrossRef] [PubMed]

10. Pells, C. Power and the Distribution of Knowledge in a Local Groundwater Association in the Guadalupe Valley, Mexico. In Collaborative Governance Regimes; Emerson, K., Nabatchi, T., Eds.; Georgetown University Press: Washington, DC, USA, 2015; pp. 136-156. ISBN 978-162-616-254-9. 
11. López-Valle, S. Élites Gerenciales en la Gestión Participativa del Agua. El Consejo Directivo del Comité Técnico de Aguas Subterráneas (COTAS) del Acuífero del Valle de San Luis Potosí (Managerial Elites in Participatory Water Management. The Board of Directors of the Underground Water Technical Committee, of the San Luis Potosí Valley Aquifer). Master's Thesis, El Colegio de San Luis, San Luis Potosí, Mexico, 2013. Available online: https://colsan.repositorioinstitucional.mx/jspui/handle/1013/339 (accessed on 10 March 2021).

12. Wester, P.; Sandoval-Minero, R.; Hoogesteger, J. Assessment of the development of aquifer management councils (COTAS) for sustainable groundwater management in Guanajuato, Mexico. Hydrogeol. J. 2011, 19, 889-899. [CrossRef]

13. Marañon, B. El espejismo de la descentralización y participación social en la gestión del agua subterránea en México (Themirage of decentralization and social participation in groundwater management in Mexico). In Agua Subterránea: Gestión y Participación Social en Guanajuato (Groundwater: Management and Social Participation in Guanajuato); Marañon, B., Ed.; UNAM, Instituto de Investigaciones Económicas: Ciudad de México, Mexico, 2010; pp. 25-65. ISBN 978-607-7700-79-1.

14. Pérez-Fuentes, J. La participación social en los COTAS: El limitado papel de los usuarios en la gestión del agua (Social participation in COTAS: The limited role of users in water management). In Agua Subterránea: Gestión y Participación Social en Guanajuato (Groundwater: Management and Social Participation in Guanajuato); Marañon, B., Ed.; UNAM, Instituto de Investigaciones Económicas: Ciudad de México, Mexico, 2010; pp. 67-106. ISBN 978-607-7700-79-1.

15. Becerril-Piña, R.; Mastachi-Loza, C.A.; González-Sosa, E.; Díaz-Delgado, C.; Bâ, K.M. Assessing desertification risk in the semi-arid highlands of central Mexico. J. Arid Environ. 2015, 120, 4-13. [CrossRef]

16. National Water Commission. Statistics on Water in Mexico 2018. México: Ministry of the Environment and Natural Resources, National Water Commission. Available online: http://sina.conagua.gob.mx/publicaciones/EAM_2018.pdf (accessed on 12 January 2021).

17. Diario Oficial de la Federación (DOF). Acuerdo por el que se Actualiza la Disponibilidad Media Anual de Agua Subterránea de los 653 Acuíferos de los Estados Unidos Mexicanos, Mismos que Forman Parte de las Regiones Hidrológico-Administrativas que se Indican (Average Anual Availability of the 653 Aquifers of the United Mexican States, Which Are Part of the Indicated Hydrological-Administrative Regions). 2020. Available online: http:/ /www.dof.gob.mx/nota_detalle.php?codigo=5600593\& fecha $=17 / 09 / 2020$ (accessed on 5 March 2021).

18. Diario Oficial de la Federación (DOF). Programa Nacional Hídrico 2020-2024 (National Water Plan). 2020. Available online: https: / / www.dof.gob.mx/nota_detalle.php?codigo=5609188\&fecha=30/12/2020 (accessed on 12 January 2021).

19. Diario Oficial de la Federación (DOF). Ley de Aguas Nacionales (Mexican Water Act). 1992. Available online: http://www. diputados.gob.mx/LeyesBiblio/pdf/16_060120.pdf (accessed on 12 January 2021).

20. Villada-Canela, M.; Martínez-Segura, N.; Daesslé, L.; Mendoza-Espinosa, L. Fundamentals, obstacles and challenges of public participation in water Management in Mexico. Tecnol. y Cienc. del Agua 2019, 10, 12-46. [CrossRef]

21. National Water Commission. Programa Hidrico Regional Visión 2030. Región Hidrológico-Administrativa I Península de Baja California (Regional Water Program Vision 2030. Hydrological-Administrative Region I Baja California Peninsula); Ministry of the Environment and Natural Resources: Ciudad de México, Mexico, 2012.

22. Daesslé, L.W.; Sánchez, E.C.; Camacho, V.F.; Mendoza, L.G.; Carriquiry, J.D. Geochemical evolution of the coastal Maneadero aquifer during a dry year in Baja California. Hydrogeol. J. 2005, 13, 584-595. [CrossRef]

23. Daesslé, L.W.; Pérez-Flores, M.A.; Serrano-Ortiz, J.; Mendoza-Espinosa, L.; Manjarrez-Masuda, E.; Lugo-Ibarra, K.C.; Treviño, G. A geochemical and 3D-geometry geophysical survey to assess artificial groundwater recharge potential in the Pacific coast of Baja California, Mexico. Environ. Earth Sci. 2014, 71, 3477-3490. [CrossRef]

24. Flores-Lugo, I.P. Presencia de Esteroles Fecales, Plaguicidas y Alquilfenoles en Aguas Subterráneas y su Relación con el Tipo de uso de Suelo en el Valle de Maneadero, Baja California (Presence of Fecal Sterols, Pesticides and Alkylphenols in Groundwater and its Relationship with the Type of Land Use in the Maneadero Valley, Baja California). Master's Thesis, Centro de Investigación Científica y de Educación Superior de Ensenada, Baja California (CICESE), Ensenada, Mexico, 2016.

25. Gilabert-Alarcón, C.; Daesslé, L.W.; Salgado-Méndez, S.O.; Pérez-Flores, M.A.; Knöller, K.; Kretzschmar, T.G.; Stumpp, C. Effects of reclaimed water discharge in the Maneadero coastal aquifer, Baja California, Mexico. Appl. Geochem. 2018, 92, 121-139. [CrossRef]

26. Mendoza-Espinosa, L.G.; Daesslé, L.W. Consolidating the use of reclaimed water for irrigation and infiltration in a semi-arid agricultural valley in Mexico: Water management experiences and results. J. Water Sanit. Hyg. Dev. 2018, 8, 679-687. [CrossRef]

27. Diario Oficial de la Federación (DOF). Decreto por el que se Establece Veda Para el Alumbramiento de Aguas del Subsuelo en el Estado de Baja California, Mexico (Decree Establishing a Closure for Groundwater Extraction in Baja California). 1965. Available online: http:/ / www.dof.gob.mx/nota_to_imagen_fs.php?codnota=4616319\&fecha=15/05/1965\&cod_diario=198386 (accessed on 12 January 2021).

28. Elizondo, L.; Mendoza-Espinosa, L. An analysis of water scarcity in a drought prone city: The case of Ensenada, Baja California, Mexico/Un análisis de la escasez de agua en una ciudad sujeta a sequías: El caso de la ciudad de Ensenada, Baja California, México. Tecnol. y Cienc. del Agua 2020, 11, 1-55. [CrossRef]

29. Gilabert-Alarcón, C.; Salgado, S.; Daesslé, L.W.; Mendoza-Espinosa, L.G.; Villada-Canela, M. Regulatory challenges for the use of reclaimed water in Mexico: A case study in Baja California. Water 2018, 10, 1432. [CrossRef]

30. Villada-Canela, M.; Camacho-López, R.; Muñoz-Pizza, D.M. The Socio-Ecological Systems Approach to Research the Integrated Groundwater Management in an Agricultural Dryland in Mexico. In Stewardship of Future Drylands and Climate Change in the 
Global South; Lucatello, S., Huber-Sannwald, E., Espejel, I., Martínez-Tagüeña, N., Eds.; Springer: Cham, Switzerland, 2020. [CrossRef]

31. Corbin, J.; Strauss, A. Basics of Qualitative Research: Techniques and Procedures for Developing Grounded Theory, 4th ed.; Chapter 5; Strategies for Qualitative Data Analysis; SAGE Publications: Thousand Oaks, CA, USA, 2014; ISBN 978-148-335-559-7.

32. Farmer, T.; Robinson, K.; Elliott, S.J.; Eyles, J. Developing and implementing a triangulation protocol for qualitative health research. Qual. Health Res. 2006, 16, 377-394. [CrossRef]

33. Talaue, G.M.; AlSaad, A.; AlRushaidan, N.; AlHugail, A.; AlFahhad, S. The impact of social media on academic performance of selected college students. Int. J. Adv. Inf. Technol. 2018, 8, 27-35. [CrossRef]

34. Mendoza-Espinosa, L.G.; Burgess, J.E.; Daesslé, L.; Villada-Canela, M. Reclaimed water for the irrigation of vineyards: Mexico and South Africa as case studies. Sustain. Cities Soc. 2019, 51, 101769. [CrossRef]

35. Salgado-Méndez, S.; Gilabert-Alarcón, C.; Daesslé, L.W.; Mendoza-Espinosa, L.; Avilés-Marín, S.; Stumpp, C. Short-Term Effects on Agricultural Soils Irrigated with Reclaimed Water in Baja California, México. Bull. Environ. Contam. Toxicol. 2019, 102, 829-835. [CrossRef] [PubMed]

36. Bagheri, M.; Kholgi, M.; Hosseini, S.M.; Amiraslani, F.; Hoorfar, A. Participatory approach in Aquifer Storage and Recovery management in Arid zones, does it work? Groundw. Sustain. Dev. 2020, 10, 100368. [CrossRef]

37. Comisión Estatal de Servicios Públicos de Ensenada, CESPE. Breve Historia. Available online: http://www.cespe.gob.mx/ public/historia (accessed on 5 July 2021).

38. Periódico Oficial del Estado de Baja California. Plan. Estatal de Desarrollo 2020-2024. Sección IV Poder Ejecutivo Estatal; Secretaría General de Gobierno: Mexicali, Mexico, 2020.

39. Valdés-Barrera, A. Análisis Organizacional del Comité Técnico de Aguas Subterráneas y su Eficacia en la Gestión Integral de los Recursos Hídricos en el Acuífero Guadalupe, B.C. (Organizational Analysis of the Groundwater Technical Committee and its Effectiveness in the Comprehensive Management of Water Resources in the Aquifer Guadalupe, B.C.). Master's Thesis, El Colegio de la Frontera Norte, A.C., Tijuana, BC, Mexico, 2014.

40. Gobierno de Baja California, XXIII Ayuntamiento de Ensenada. Plan. Estratégico Metropolitano de Ensenada. Visión 2034; Consejo de Desarrollo Económico de Ensenada: Ensenada, BC, Mexico, 2019.

41. Periodico Oficial del Estado de Baja California. Acuerdo de Creación del Instituto Metropolitano de Investigación y Planeación de Ensenada, Baja California. Tomo CXXVI; Gobierno de Baja California: Mexicali, BC, Mexico, 2019.

42. Grigg, N.S. Leadership for Sustainable Water Management: Challenges and Opportunities. Leadersh. Manag. Eng. 2011, 11, 121-127. [CrossRef]

43. Galvez, V.; Rojas, R.; Bennison, G.; Prats, C.; Claro, E. Collaborate or perish: Water resources management under contentious water use in a semiarid basin. Intl. J. River Basin Manag. 2020, 18, 421-437. [CrossRef]

44. Berg, S.V. Seven elements affecting governance and performance in the water sector. Util. Policy 2016, 43, 4-13. [CrossRef]

45. Pineda-Pablos, N.; Moreno-Vázquez, J.L.; Díaz-Caravantes, R.E. La capacidad institucional de los consejos de cuenca en México. El caso del Alto Noroeste 1999-2017 (The institutional capacity of the basin councils in Mexico. The case of the Upper Northwest, 1999-2017). Reg. Soc. 2019, 31, 1-23. [CrossRef]

46. van der Hel, S. New science for global sustainability? The institutionalisation of knowledge co-production in Future Earth. Environ. Sci. Policy 2016, 61, 165-175. [CrossRef]

47. Ingram, J.; Gaskell, P.; Mills, J.; Dwyer, J. How do we enact co-innovation with stakeholders in agricultural research projects? Managing the complex interplay between contextual and facilitation processes. J. Rural Stud. 2020, 78, 65-77. [CrossRef]

48. Honkonen, T.; Lipponen, A. Finland's cooperation in managing transboundary water and the UNECE Principles for Effective Joint Bodies: Value for water diplomacy? J. Hydrol. 2018, 567, 320-331. [CrossRef]

49. Kauffman, C.M. Financing watershed conservation: Lessons from Ecuador's evolving water trust funds. Agric. Water Manag. 2014, 145, 39-49. [CrossRef]

50. Piyapong, J.; Thidarat, B.; Jaruwan, C.; Siriphan, N. Enhancing citizens' sense of personal responsibility and risk perception for promoting public participation in sustainable groundwater resource management in Rayong Groundwater Basin, Thailand Groundw. Sustain. Dev. 2019, 9, 100252. [CrossRef]

51. Jonsson, A.C.; Andersson, L.; Olsson, J.A.; Johansson, M. Defining goals in participatory water management: Merging local visions and expert judgements. J. Environ. Plan. Manag. 2011, 54, 909-935. [CrossRef]

52. Ker-Rault, P.A.; Vreugdenhil, H.; Jeffrey, P.; Slinger, J.H. Readiness and willingness of the public to participate in integrated water management: Some insights from the Levant. Water Policy 2013, 15, 101-120. [CrossRef]

53. Arun, G.; Singh, D.R.; Kumar, S.; Kumar, A. Canal Irrigation management through water users associations and its impact on efficiency, equity and reliability in water use in Tamil, Nadu. Agric. Econ. Res. Rev. 2012, 25, 409-419. [CrossRef]

54. Sheikh, M.J.; Redzuan, M.B.; Samah, A.A.; Ahmad, N. Factors influencing farmers' participation in water management: A community development perspective. IOSR J. Humanit. Soc. Sci. 2014, 19, 59-63. [CrossRef]

55. Wanjala, N. The Role of Women in the Management of Water Resources in Bungoma West District, Western Kenya. Ph.D. Thesis, University of Nairobi, Nairobi, Kenya, 2009. 